\title{
PUTUSAN VERSTEK BERDASARKAN KETIDAKHADIRAN TERGUGAT DENGAN RELAAS YANG DI SAMPAIKAN KEPADA KEPALA DESA (STUDI KASUS PENGADILAN AGAMA MALANG)
}

Samsia $^{1}$, Ach. Faisol ${ }^{2}$, Nurhasan ${ }^{3}$

Prodi Ahwal Syakhshiyyah Fakultas Agama Islam Universitas Islam Malang

Email: samsiaciya@gmail.com, ach.faisol@unisma.ac.id, nur.hasan@unisma.ac.id

Diterima: 12-09-2020 | Direvisi: 12-09-2020 | Disetujui: 12-09-2020

(C) 2019 Program Studi Ahwal Syakhshiyyah Fakultas Agama Islam Universitas Islam Malang

\begin{abstract}
The verstek decision is a decision that the defendant does not attend at the beginning of the first trial and is still absent for the hearing on the following day. The impact when the defendant is not there is that the defendant does not know the trial schedule. Then the verstek trial was held by a summons from the trial through the substitute clerk of the court. The substitute clerk makes a summons at the residence of the defendant. If the defendant is not in the residence, then the call is sent through the family, neighbors or the village head. From the results of the judges' considerations, the Verstek decision was the verdict handed down by the judge outside the presence of the defendant. In the Verstek decision, there is a statement that the defendant is absent even though he has been properly summoned. In this study there are two legal remedies, ordinary legal remedies namely those used not yet fixed, such as technology, appeal and cassation and extraordinary remedies namely those used permanent legal force. For example, reconsideration and third party resistance.
\end{abstract}

Keywords: verstek decision; relaas; village head..

\section{A. Pendahuluan}

Pengadilan Agama adalah salah satu dari empat pilar. Mahkamah agung membawa pilar tersebut dari tahun 2005 Empat pilar tersebut adalah sebagai berikut:

1) Pengadilan negeri

2) Pengadilan Agama di Kota/kab

3) Pengadilan militer

4) Pengadilan tata usaha diibukota

Apabila ada salah satu pihak atau suami istri tidak menjalani kesepakatan harus dieksekusi. Ketika memeriksa gugatan selesai membaca, majelis akan

This work is licensed under Creative Commons Attribution Non Commercial 4.0 International License Available online on: http://riset.unisma.ac.id/index.php/fai/index 
menanyakan kekurangan, kelebihan didalam isi gugatan tersebut. Gugatan adalah seseorang yang datang ke pengadilan dengan membawa surat gugatan. Cerai gugatan itu adalah istri dan cerai talak itu adalah suami. Di pengadilan agama malang pada zaman dulu gugatan itu dibuat oleh PA tapi sekarang dibuat sendiri atau minta bantuan. Perbedaan gugatan dan permohonan, kalau gugatan ada lawan sedangkan permohonan tidak ada lawan. Ada beberapa unsur gugatan yaitu: tanggal, kepada (identitas), hal gugatan, positas (hukum yang melandasi masalah), dan petitum (permintaan). Gugatan itu terkadang tidak diterima oleh hakim. Alasan mendasar karena posita. Positanya tidak sesuai hukum dan tidak ada kesesuaian. Persyaratan pokok cerai adalah buku nikah dan KTP. KTP diserahkan didalam persidangan. Sidang pertama:

1) ada penggugat tidak hadir, tergugat hadir, jadi hakim bisa menggugurkan gugatan penggugat. Ada penggugat tidak hadir, tergugat tidak hadir, maka hakim boleh menggurkan perkara atau ada penggugat hadir, maka hakim boleh mengugurkan perkara atau

2) ada penggugat hadir, tergugat tidak hadir, maka hakim memutukan keputusan verstek.

Sidang kedua:

1) mendengar hasil laporan mediasi

2) kalau gagal mediasi, hakim mengutarakan "sidang tertutup untuk umum"

3) ketua majelis membaca surat penggugat

4) jawaban tergugat berbentuk tulisaLlisan.

Sidang ketiga:

1) hakim membaca "tertutup untuk umum"

2) agenda pembuktian sidang terakhir:

1) hakim tetap membuat perdamaian kedua belah pihak

2) hakim menanyakan pembuktian tergugat.

Pengadilan setelah menerima perkara kewajibannya itu memanggil para pihak. Ketika memanggil para pihak itu harus sah panggilan dan disampaikan kepada jurusita, dari kantor pengadilan menuju alamat sesuai dengan alamat yang tertuang. Sah itu artinya oleh jurusita dan ada tenggang waktu 3 hari dari panggilan ke menggelar sidang pertama itu. Jika ada pihak-pihak yang tidak hadir, harus tau alasan dasarnya. Kalau yang tidak hadir itu penggugat ,hakim bisa mengambil sikap untuk menggugurkan yang penting panggilannya patut dan hakim juga bisa menunda. begitu juga kalau yang tidak hadir itu tergugat hakim

JAS: Volume 2 Nomor 2, 2020 
Putusan Verstek Berdasarkan Ketidakhadiran Tergugat

Dengan Relaas Yang Di Sampaikan

Kepada Kepala Desa (Studi Kasus Pengadilan Agama Malang)

juga bisa langsung memutuskan dengan putusan verstek. Tapi kalau hakim masih ingin menunda di perbolehkan.

Ketika bertemu alamat tergugat harus dipastikan apakah diatinggal didomisili atau tidak, selanjutnya ketika tidak ada tergugat ditempat kediamannya Tanya kekeluarganya atau tetangga. Kadang alamat itu, belum tentu pihak berada disitu juga, jadi dipastikan ketetanggaapan benar di masih berdomisili atau tidak. Biasa dari petugas Pengadilan Agama Malang memberi surat panggilan ke alamat yang bersangkutan atau lewat tetangga, setelah itu menuju kediaman kelurahan dan meminta tanda tangan stempel kelurahan bahwa sebagai bukti sudah kerumah yang bersangkutan. Menurut undangundang harus kelurahan yang menyampaikan ke yang bersangkutan, tetapi dari jurusita menyadari bahwa petugas kelurahan tidak terlalu banyak jadi dari jurusita saja yang menyampaikan sendiri ke yang bersangkutan.

Ketika ada penolakan dari kelurahan harus tau dasarnya. Dari Pengadilan Agama Malang belum pernah terjadi penolakan atau tidak respon dari kepala desa/kelurahan karena tahap-tahap relaas sudah sesuai dan penyampaian langsung kealamat yang bersangkutan.

Ada dua relaas ketika memanggil tergugat/penggugat

1) Bertemu tergugat/penggugat tanpa melalui kelurahan

2) Tidak bertemu dan harus melalui kelurahan/kepala desa

Tujuan dari penelitian untuk mengetahui atau untuk mendiskripsikan bagaimana proses verstek di pengadilan-pengadilan, baik pengadilan Agama maupun pengadilan Negeri, dan apa pertimbangan hakim dalam memutuskan verstek tersebut, serta bagaimana upaya hukum memutuskan putusan verstek tersebut. Sehingga kita mengetahui permasalahan-permasalahan yang ada di masyarakat.

\section{B. Metode Penelitian}

Adapun metode kajian yang digunakan dalam penelitian tentang Putusan verstek ini adalah sebagai berikut: Pendekatan yang diterapkan dalam kajian sederhana ini adalah lebih ke arah pendekatan yang bersifat kualitatif. Dalam penelitian yang dilakukan oleh peneliti mengunakan Pendekatan kualitatif Deskriptif dimana pada penelitian yang dilakukan harus berupa paparan data.

JAS: Volume 2 Nomor 2, 2020 
Menurut Achmad faishol bahwa penelitian lapangan dilakukan dengan cara mengamati (observasi) bertemu bahkan barkawan dan bergaul bertahun-tahun,

Adapun jenis penelitain yang dilakukan oleh peneliti adalah studi kasus, maka menurut yin bahwa studi kasus merupakan proses penelitian tentang pengujian pertanyaan dan masalah penelitian yang tidak bisa dipisahkan antara fenomena dan konteks penelitian itu sendiri karena studi kasus harus fokus pada satu titik agar data yang dikumpulkan akurat. Studi kasus yang dilakukan oleh peneliti bertempat di Pengadilan agama Kota Malang, kehadiran peneliti disana selama 1 bulan sehingga data yang diambil banyak terkait putusan verstek yang berkaitan dengan proses verstek, pertimbangan hakim, dan upaya hukumnya.

\section{Hasil Dan Pembahasan}

Dalam pertimbangan hukum dipertimbangkan hakim adalah eksepsi tergugat, jika dalam jawab antar dapat eksepsi. Kalau tidak ada eksepsi hakim langsung mempertimbangkan pokok perkara. Pertimbangan pokok perkara diawali dengan pertimbangan apa yang dimasalahkan penggugat dalam surat gugatnya, kemudian tentang bagaimana jawaban tergugat. Apabila terjadi perbedaan dalil penggugat dengan dalil tergugat, maka hakim didalam pertimbangan hukumnya akan mempertimbangkan dalil penggugat dengan alatalat bukti yang diajukannya. Kemudian hakim akan mempertimbangkan dalil tergugat dengan alat-alat buktinya. Jika dalam pertimbangan pembuktian itu hakim menilai pembuktian penggugat lebih kuat maka penggugat berhasil membuktikan gugatannya. Sebaliknya jika tergugat yang lebih kuat pembuktiannya, maka penggugat tidak berhasil membuktikan gugatannya dan gugatan harus ditolak seluruhnya.

Pasal putusan verstek ada dua pasal khusus yaitu: pasal 125 ayat $3 \mathrm{itu}$ khusus untuk jawa dan pasal 149 ayat 3 khusus luar jawa dan madura. 3 hari sebelum sidang tergugat harus dipanggil secarah sah.

perbedaan verstek dan kontraditor adalah kalau verstek lawannya tidak hadir sedangkan kontraditor lawannya hadir tetapi ketika hari putusan tidak hadir. Cerai gugatan setelah 14 hari suami boleh menikah lagi, dan untuk istri belum diperbolehkan kecuali setelah massa iddahnya.

Putusan Hakim didalam perkara perdata merupakan jawaban dari gugatan penggugat. Dalam putusan dapat diketahui apakah gugatan penggugat berhasil atau tidak dikatakan dengan istilah "berhasil atau tidak berhasil" karena ingin membedakan dengan istilah gugatan dikabulkan atau ditolak. Jika JAS: Volume 2 Nomor 2, 2020 


\section{Putusan Verstek Berdasarkan Ketidakhadiran Tergugat \\ Dengan Relaas Yang Di Sampaikan \\ Kepada Kepala Desa (Studi Kasus Pengadilan Agama Malang)}

disebutkan ditolak, maka akibatnya penggugat tidak lagi dapat mengajukan gugatan untuk sengketa yang sama.

Asas dalam hukum perdata penggugat itu tidak ada gugatan penggugat itu dianggap benar. Karena di anggap benar, maka hamper tidak ada gugatan verstek itu ditolak, Kecuali gugatan itu ada cacat formil. Cacat formil itu artinya gugatannya salah,ospur (kabur) antara posita dengan petitum, alamat tidak sesuai atau tidak jelas, nama orang yang dituju itu kurang, dan lain sebagainya. Jadi hakim bukan menolak hakim menyatakan gugatan itu cacat sehingga dari majelis hakim gugatan tidak dapat diterima. Tetapi Sepanjang tidak ada cacat dalam gugatan, karena ketidakhadiran tergugat maka berarti otomatis gugatannya dianggap benar. Karena dianggap benar maka hakim memutuskan putusan tersebut dengan putusan verstek.

Contoh cacat didalam gugatan diantaranya adalah:

1) Diskualisasi inpersonal.

2) Nepis in idem perkara ialah tersebut sudah pernah diputus dan diajukan lagi dipengadilan.

3) Permatur belim waktunya cerai tetapi pihak mengajukan percerain. Misalnya belum menikah tapi sudah mengajukan cerai.

4) Eror in personal orangya salah.

5) Obsturlibel kabur atau gugatannya tidak jelas, tidak nyambung antara posita dengan petitum.

\section{Simpulan}

Kalau tergugat tidak pernah hadir sama sekali maka putusan perkaranya lebih cepat, tetapi kalau tergugat kadang hadir kadang tidak justru perkaranya akan lama. Misalnya sidang pertama tergugat tidak hadir selanjutnya siding kedua tergugat hadir untuk siding ketiga hakim jangan langsung diputus tetapi pengadian harus memanggil tergugat lagi karena pada dasarnya setiap persidangan para pihak itu harus dipanggil. Panggilan itu melewati jurusita langsung kealamat para pihak dan bisa juga panggilan para pihak langsung ketika didalam ruang persidangan. Pihak penggugat juga harus dipanggil Tetapi tidak perlu dipanggil oleh jurusita cukup diperintahkan dalam sidang. Kelebihan kalau panggilan para pihak didalam persidangan tidak mengeluarkan biaya sedangkan kalau panggilannya melewati jurusita maka mengeluarkan biaya. Asasnya setiap kali persidangan harus ada panggilan atau harus dipanggil. Syarat verzet: 1 . JAS: Volume 2 Nomor 2, 2020 
Samsia, Ach. Faisol, Nurhasan

Harus ada putusan verstek terlebih dahulu. 2 Diajukan tidak boleh lewat dari 14 hari.

\section{Daftar Rujukan}

Khoirul Asfiyak, Ikhtilaf Al-Fuqaha: Studi Tentang Akar Perbedaan Pemikiran Hukum Islam, JAS: Jurnal ilmiah Akhwal Syakhsiyyah UNISMA Vol 2 Nomer 1 tahun 2020.

Harahap, M.Yahya. 2016. Hukum Acara Perdata Tentang Gugatan, Persidangan, Penyitaan, Pembuktian Dan Putusan Pengadilan. Jakarta:Sinar Grafika.

M. Fauzan.2005. Pokok-Pokok Hukum Acara Perdata Peradilan Agama dan Mahkamah Syar'iyah diIndonesia. Jakarta: Kencana.

Supramono, Gatot. 2008. Bagaimana Mendampingi Seseorang Di Pengadilan Dalam Perkara Pidana Dan Perdata. Jakarta:Djambatan.

JAS: Volume 2 Nomor 2, 2020 